\title{
Article
}

\section{Roberto Frega The Social Ontology of Democracy}

https://doi.org/10.1515/jso-2018-0025

\begin{abstract}
This paper offers an account of the social foundations of a theory of democracy. It purports to show that a social ontology of democracy is the necessary counterpart of a political theory of democracy. It notably contends that decisions concerning basic social ontological assumptions are relevant not only for empirical research, but bear a significant impact also on normative theorizing. The paper then explains why interactionist rather than substantialist social ontologies provide the most promising starting point for building a social ontology of democracy. It then introduces and examines the three notions of habits, patterns of interaction, and forms of social organization, conceived as the main pillars of an interactionist social ontology of democracy and briefly discusses some major implications of this approach for democratic theory.
\end{abstract}

Keywords: Social ontology; Democratic theory; Social interactionism; Democracy; Political ontology.

\section{Introduction}

This paper is motivated by the double awareness that whilst ontological premises seem to be an inescapable presupposition of all normative thinking, a "radical absence of ontological rigour" continues to plague the social sciences (Elder-Vass 2010, p. 64) and, I hasten to add, the political sciences even more so. Political theorists have systematically eschewed ontological talk, likely because of its supposed obscurity and metaphysical leanings, but also because of its apparent irrelevance for normative theorizing. Yet ontological premises inevitably shape the most basic assumptions upon which political theories are built, even when, perhaps especially when, these premises are not spelled out

Roberto Frega, Centre National de la Recherche Scientifique, Paris, France, e-mail: fregarob@gmail.com. https://orcid.org/0000-0002-6556-4275

¿ Open Access. ( 2018, Roberto Frega, published by De Gruyter. (c) BY the Creative Commons Attribution 4.0 Public License. 
explicitly. ${ }^{1}$ Ontology describes the basic constituents of a given theory. In the case of politics, it specifies the basic entities of the theory, such as individuals, groups, and institutions, articulates its basic properties, and describes the relation they entertain. Ontological premises bear consequences not only on theoretical and methodological assumptions, but also on the very normative claims a political theory utters. No matter whether a theory espouses a liberal understanding of the normative priority of individual autonomy, a republican or communitarian commitment to the priority of collective forms of obligation, or a marxist predilection for structural forms of societal organization, a social ontology is always assumed, often without a serious examination of its conditions of validity and of its theoretical implications. ${ }^{2}$

As I conceive it, ontology is a critical discourse on the basic categories through which our understanding of the world is shaped. Its goal is to provide an account of the fundamental entities and structures of social existence, as well as of its main social dynamics. My first contention is that more than a political ontology, political theory needs a social ontology. Whereas political ontology is concerned with categories that bear directly on the explanation of political phenomena such as voting, protest, or conflict-resolution, social ontology has a much broader scope, as it is concerned with the categories required to give an account of the layers or dimensions of social life that are most relevant for understanding normative properties related to collective action. In other words, social ontology is concerned with the social underpinnings of normative concepts such as justice, democracy, equality, understood as social norms whose domain of application is larger than that of political behavior and institutions. By speaking of a social ontology of democracy I mean, moreover, to restrict the focus of attention to those social circumstances which are relevant not for any type of political investigation whatsoever, but specifically for understanding democracy as a norm for steering social life.

A social ontology of democracy, therefore, aims at uncovering the social underpinnings of a normative theory of democracy, understood not as a formal political system, but as a norm capable that can be applied to social life in its entirety. ${ }^{3}$ Underlying this approach is the view that democracy as a social norm does not refer merely to a given set of formal political institutions, but more extensively to a set of normative expectations that are relevant for the organization of

1 For an overview of this topic, see Hay (2006). See Pettit (2005) for a basic statement on the role of ontology in political theory, and Gould (1988, Ch. 2) for an extended discussion of the social ontological underpinning of mainstream models of democracy.

2 Some significant exceptions are Gould (1978); Pettit (2014); Taylor (1985); Hay (2006).

3 I discuss more broadly this "paradigmatic” conception of democracy in Frega (2017a). 
collective life in its entirety (Frega 2017b). The referent of democracy, according to this view, is an entire "form of society" (Lefort 1986), or "way of life" (Dewey 1939). What is normative about this concept is that it refers to appropriate ways of behavior. The normative scope of democracy, to this extent, is not limited to the prescription of obligatory actions, but encompasses different deontic values such as right, appropriate, legitimate, or desirable.

By emphasizing the social-ontological underpinnings of democracy as a norm, this paper purports to show that the basic ingredients that one usually finds at the basis of political ontologies - individual preferences and actions, and formal political institutions - are insufficient, even when combined together, to account for the normative fact conveyed by the idea of democracy as a norm for steering social life. What political ontologies fail to explain, I will contend, is the normative relevance of social interactions.

This paper contends therefore that (1) democratic theory requires an explicit examination of its own ontological underpinnings, and that (2) a social ontology provides the most promising foundation for such a task. It further contends that (3) the most appropriate type of social ontology to fulfill this task is an interactionist social ontology and, lastly (4) that individual habits, patterns of interaction, and organizational forms provide the basic ingredient of such an ontology. In the first section of the paper I provide an overview of ontological debates in the social and political sciences and explain why we need a social, rather than a political ontology. Sections 2 justifies the preference for an interactionist social ontology of democracy, and Section 3 discusses its normative features. Section 4 provides a first discussion of the normative implications of interactionist ontologies. Section 5 introduces the major features of my proposal for an interactionist social ontology of democracy.

\section{From Political to Social Ontology}

In its most basic and conventional terms, social ontologies have traditionally been divided into two major camps, that philosophers have preferentially described with the terms of "atomism" and "holism", and sociologists with those of "agency" and "structure". ${ }^{4}$ Atomist and agent-based theories contend that individuals and their traits such as preferences, intentions, or actions are

4 See, for example, Zahle and Collin (2014) for the holism vs. individualism debate, and ElderVass (2010) for the agency vs. structure debate. These may not be the most widespread categories one finds in philosophical debates sparked by the work of John Searle, or in analytic ontology, mereology, and related sub-field, but are by far the most relevant conceptual distinctions when it comes to political theory. See, for example, Pettit (2014). 
the final explanans in philosophy and social theory, so that any supra-individual phenomena such as electoral results, consumption trends, or life-styles, can be explained with reference to them. Holistic and structure-based approaches reverse the order of explanation, and strive to explain how individual factors such as values, beliefs, and behaviors, can be explained as the result of the interplay of super-ordained structures such as ideologies, sociological attributes, or economic determinants. A century long debate in philosophy has been going on over the supposed priority of either of the two categories, and the agency vs. structure problem has equally occupied sociologists for at least three generations (Zahle and Collin 2014; Epstein 2015). At the heart of both debates stands the vexed question of the mode of existence of individual and collective agents. Formulated as such, the problem is probably unsolvable.

It has been suggested that a way out of this impasse may consist in assuming that rather than flawed, the opposition between agency-based and structurebased social ontologies is incomplete. Relational and processual ontologies in philosophy, and interactionist ontologies in social theory have notably contended that atomism and agency on the one hand, and holism and structure on the other do not exhaust the entire spectrum of ontological thinking, but merely that of substantialist ontologies, which have to be distinguished from other, nonsubstantialist, types of ontologies, usually defined as relational, processual, or interactionist. ${ }^{5}$ Substantial ontologies on the one hand, and interactionist ontologies on the other, differ in what they take to be primitive: substantial ontologies of any stripe, no matter whether atomistic, holistic, or other, share the assumption of the primacy of substance over relations, interactions, and becoming, whereas interactionist ontologies reverse the order of explanation, giving priority to relations, interactions, and becoming over substance. From this broader perspective, substantialist ontologies have been criticized wholesale for their inadequate consideration of the effects of social practices and patterns of interaction in the constitution of social reality. ${ }^{6}$ The juxtaposition between atomist and holist

\footnotetext{
5 For this distinction in philosophy, see Renault (2016), and see Emirbayer (1997) for an equivalent discussion within social theory and sociology. It will be noted that both authors rely on American pragmatism to formulate their criticism of substantialist ontologies.

6 Classical attempts at overcoming the agency vs. structure dualism are (Giddens 1984; Archer 1995). Social theories of practice often share the same ontological assumptions. More recent attempts are exemplified by Daniel Little's notion of meso-meso causal relations (Little 2012), Dave Elder-Vass' theory of normative circles (Elder-Vass 2010), and Lars Udehn's theory of "structural individualism" (Udehn 2002).
} 
ontologies can then be replaced by the more encompassing distinction between substantialist and interactionist ontologies.

This neglect of social interaction is particularly evident in political theory. Indeed, even when it has consciously striven to work out its own ontological premises, political theory has generally subscribed to substantialist ontologies, and has remained captive of the dualistic split between atomist and holistic ontologies, that can be conventionally traced back to the political thought of Thomas Hobbes and Jean-Jacques Rousseau. Atomist and holistic political ontologies have provided for centuries the most basic and opposed models through which relations among citizens, and relations of citizens to governments, have been conceptualized. In contemporary political theory, liberalism tends generally to espouse atomistic assumptions concerning the psychological, moral, and legal priority of individuals, whereas communitarian conceptions focus instead on the preeminence of groups and communities over individual properties. ${ }^{7}$ On the one hand, atomism conveys an interpretation of society as an aggregation of autonomous selves, with the ensuing idea of the people as an aggregate of individual wills. On the other hand, we find the holistic idea of society as a collective entity endowed with emergent and autonomous properties and capable of shaping the identity of its members, with the ensuing idea of the people as a single body endowed with a "general will".

In line with this dualist split, political theory tends to locate democracy's legitimacy either at the level of the individual, or at that of institutions. On the one hand, a strand of political theorists locates the spring of political legitimacy in individual properties such as beliefs, preferences, or interests, conceived as the distinctive attribute of rational individual actors. From this perspective, the interactions that are relevant for political ontology "are those that involve the intentional attitudes of participants: that is, the attitudes that bulk large in the psychology of persons", (Pettit 2014, p. 78). On the other hand, another strand of political theorists assigns this task to formal political institutions in their capacity to steer society through structural features such as procedural legitimacy, due process, separation of powers, constitutional guarantees, etc. Political science has generally followed suit, its main branches being de facto divided into studies of individual political behavior on the one hand, and studies of formal political

7 Charles Taylor has notably contended that the deepest roots of the liberal-communitarian divide are ontological, as ontologies express different models of the way individuals live together in society (Taylor 1995). But see also, in a longer temporal perspective, the harsh polemics between individualism and collectivism initiated by Karl Popper's distinction between open and close society (Popper 1945). 
institutions on the other. In either way, the intermediate dimension of patterns of social interaction has systematically been neglected.

Under the dominance of these two tendencies, the normative relevance of patterns of social interaction has been lost from view, either reduced to the aggregate effect of individual actions or beliefs, or deduced as the structural result of the operation of formal political institutions. A relational social ontology of democracy strives consciously to overcome both these limitations. It does so by bringing into normative focus the interactionist dimension of social life in a manner that emphasizes its normative relevance. This requires showing in what sense the predicate "democratic" can be applied in a normatively relevant sense not only to individual and structural properties, but also to patterns of social interaction. Achieving this goal requires that political theory too, like social theory, overcomes the dualism of agency and structure with the help of a third structuring term, conceived either as an additional ontological principle, or as a most basic form capable of engendering the terms postulated by the other social ontologies. Such an approach requires in turn that the central relevance of social interactions be acknowledged in its ontological (Section 2) as well as in its normative dimension (Section 3).

\section{Social Interactionist Ontologies}

Association, process, transaction, interaction are some of the terms employed to refer to an ontological view which rejects substantialist assumptions and assigns ontological priority to interactions over substantial properties of individual and collective entities and attempt to show how these last result from interactional events. ${ }^{8}$ Interactionist social ontologies share two basic assumptions. The first and

8 In the rest of this paper I will use the expression "social interactionism" to refer in generic terms to any ontological perspective that is in line with this basic idea. Examples of process ontologies are Alfred North Withehead's metaphysics (Whitehead 1929), Arthur Bentley's (Bentley 1908) and Mary Parker Follett's (Follett 1919) political sciences, Charles Cooley' (Cooley 1918) and Andrew Abbott's social theories (Abbott 2016). Associational ontologies have been mainstream in American sociology at the turn of the 20th century (Park and Burgess 1921), and found philosophical voice in American pragmatism, for example in John Dewey's associational metaphysics (Dewey 1928). Interactionist ontologies were common also among members of the Chicago School of sociology (Bulmer 1986; Abbott 1999), and more recently in the work of Ervin Goffman and in ethnomethodology (Rawls 1987; Korbut 2014). For a broad overview of interactionist social theories, see Dépelteau (2018). 
less controversial assumption is that relations are internal rather than external. ${ }^{9}$ This means that individual identities are not primitives but, rather, shaped through the relations to which they take part. The second and more controversial assumption is that social relations have independent normative properties that cannot be reduced to nor derived from the normative properties of either individuals or structures. These normative properties need to be investigated in their own terms. This section deals cursorily with the first better known assumption, and the next section explains in what sense social interaction have distinctive normative properties.

Social interactionist ontologies share the idea that one cannot account for the complexity of reality by assigning explanatory priority to either individual or structural entities. They suggest, instead, to inscribe individual phenomena such as beliefs and actions and structural ones such as institutions, norms, and cultures within the flux of social dynamics - transactions, interactions, associations, practices, processes unfolding in time. Temporality matters insofar as individuals and institutions are seen as constantly evolving through interactions, so that more than their ontological constitution, what determines their normative properties are the consequences of interactions. Interactionists contend that social interactions play a constitutive role also in shaping normative orders. Their basic intuition is that "[t]he substratum of social life is interaction, not biological individuals who act” (Abbott 2007, p. 7). Interactions, rather than individual agents or structures, are then ontologically primitive. As Randall Collins has emphatically stated, "The smallscale, the here-and-now of face-to-face interaction, is the scene of action and the site of social actors. If we are going to find the agency of social life, it will be here. Here reside the energy of movement and change, the glue of solidarity, and the conservatism of stasis. Here is where intentionality and consciousness find their places; here, too, is the site of the emotional and unconscious aspects of human interaction. In whatever idiom, here is the empirical/ experiential location for our social psychology, our symbolic or strategic interaction, our existential phenomenology or ethnomethodology, our arena of bargaining, games, exchange, or rational choice” Collins (2004, p. 4).

Social interactionists construe social reality as the result of interaction-based processes of individualization and institutionalization which find their focus within social situations. ${ }^{10}$ By this it is of course not meant that human agents are

9 For an application of this principle to political ontology, see Gould (1988).

10 Habitualization and institutionalization are two key terms used in social theory to account for the ontological function of social interactions. The first refers to processes whereby participation in repeated social interactions shapes individual traits, whereas the second refers on the revers process whereby patterns of interaction obtain temporal stability through their institutional embodiment. Anthony Gidden's theory of structuration (Giddens 1984) is a paradigmatic attempt to combine the two into an interactionist social ontology. 
systematically determined by social laws (social interactionism is no determinism) but, rather, that some of their distinguishing attributes concerning beliefs, preferences, and interests are formed in the course of (and strongly influenced by) contextualized interactions, so that their specific content systematically depends upon the nature of such interactions. So conceived, interactions do not only shape individual identity, as scholars in this tradition have since long established, but also the nature of organizations and institutions. Social interactions acquire then a methodological priority insofar as they are seen as the generative core of social life. On the one hand, by positing social interactions rather than individual action as the basic social act, individual attributes appears as the results of social interactions. On the other hand, institutional forms are seen as the progressive stabilization and formalization of patterns of social interaction.

In both ways, what is emphasized is the generative force of social interactions in constructing social life and the normative orders that govern it, as well as the function of individual habits, social patterns, and forms of organization in providing social life with the regularity without which no social unit can exist. The upshot is that if interactions among individuals within socially situated settings is the fabric of social life and if, moreover, situations have laws or processes of their own, then exclusive focus on pre-social autonomous individuals or on formal institutions misses a decisive feature of how social life unfolds. Social interactionist approaches put this basic feature into focus.

My proposal, further explained in Sections 5 and 6 below, consists in seeing social reality as being constituted by processes of habitualization and institutionalization propelled by three main social springs: individual habits, patterns of social interaction, and organizational forms. Taken together, they help stabilize social interactions, which would otherwise fail to acquire the stability and predictability required by social life. Patterns of social interaction reproduce themselves through their inscription in individual dispositions as well as through their embodiment in social institutions and structures. Social norms succeed in steering social life only through their actuation via these social mechanisms.

Interactionist ontologies propose then to see under a different light how social orders are formed and evolve in time, how social norms concretely steer social life by becoming embedded in habits, patterns, and forms, how their effects are transmitted through different social spheres. Indeed, one of the advantages of interactionist social ontologies consists in avoiding the idealist traps related to the idea that norms are endowed with causal powers. Democracy as a norm can successfully steer social life not because norms possess some mysterious causal power, but because they are embedded in habits, patterns of interaction, and forms of organization. 
It is important to note that interactionist approaches undermine neither agents' autonomy nor political institutions' capacity to steer social life. They provide, rather, a better understanding of how individual phenomena and institutional practices can do the normative work they do. Integrating all these dimensions into a unified picture is therefore a necessary step to fully understand what do we mean when we say that democracy is a norm for steering of social life.

\section{Two Concepts of Social Order}

So far I have provided a quick overview of interactionist ontologies and pointed to some of their advantages for studying social reality, explaining why from a social interactionist standpoint exclusive focus on individual and structural properties ends up with incomplete accounts of political reality. In this section I examine the normative implications of these ontological assumptions, by explaining in what sense social interactions can be said to bear normative relevance. In order to understand the normative implications of the interactionist approach to ontology, we need to introduce an additional distinction between two types of mechanisms by which normative orders operate, sometimes referred to as "the order of interaction" and "the institutional order". I begin by discussing a conceptual distinction more familiar to philosophers, introduced by John Rawls in 1955. Rawls' paper "Two Concepts of a Rule” has become a reference in discussions of social ontology. Here Rawls distinguishes between two functions of rules, the one explaining existing regularities, the other referring to the practices that institute them. Or, in Rawls' terms, "justifying a practice as a system of rules to be applied and enforced, and justifying a particular action which falls under these rules" (Rawls 1955, p. 5). What is at stake, is "the distinction between the justification of an institution and the justification of a particular action falling under it" (Rawls 1955, p. 10). In the case of penal law discussed by Rawls, it is the difference between justifying a system of sanctions for the sake of the common good of society, and justifying a penal sanction because someone has violated a law. The difference between these two practices calls for two distinct modes of justification which, in turn, points to two distinct normative logics.

To explain this difference, Rawls distinguishes between a "summary" conception of rules, and a "practice" conception of rules. According to the summary view, rules are summaries of past decisions, so that the principles that justifies the individual occurrence and that which justifies the general rule are the same. In Rawls' example, the utilitarian rule of conduct is referred to at individual level to explain why an action is punished, and at social level to justify 
the legal system. Social order and individual action follow the same normative logic: what holds for individuals separately, holds for society collectively. The practice conception of the rule, on the other hand, conceives of social order not as the result of the sum of individual actions, but as the result of a constitutive act which institutes the order itself. In the case in point, a system of legal sanctions can be justified on utilitarian grounds, whereas what provides the norm for individual conduct (individual action or application of the law) is compliance with the social order. The individual must obey the law in the specific case not because this action would increase utility, but because the generalized compliance with the law does. In that sense justifying the action and justifying the practice follow two distinct normative logics. The two conceptions points to two conceptions of the relation between individual action and social order. According to the first, social order is the spontaneous result of individuals applying the same rules in the same manner. According to the second, it is the results of individuals accepting certain rules as defining the practice within which they act. In one case, the practice is the casual result of independent interactions. In the second, actions achieve a collective consistency because they articulate a pre-existing shared practice which defines the meaning of the actions themselves. The upshot of the second is that the meaningfulness of social action depends on the tacit or explicit acceptance of a given system of rules as defining the "game" they will play. Rawls contends that both conceptions have their own appropriate field of application, and troubles derive from misapplication.

In the footsteps of J. Rawls, Anne Rawls has further developed this distinction so as to make it the basis of an interactionist theory of action. ${ }^{11}$ As I will explain, A. Rawls' interpretation of practice rule helps explain why interactions are a non reducible dimension of social life, differentiating the order of interaction from the two competing models of explanation based on the autonomy of individual agency and the structural preeminence of supra-individual normative orders. In social theory the concept of summary rule refers to two apparently opposed and yet isomorphous phenomena she calls "institutional order". On the one hand, to how social regularities can be explained as ex post results of the rational conduct of individuals. This is what happens, for example, when we contend that political legitimacy derives from the aggregation of individual preferences through vote or other mechanisms. Such a way of proceeding "elevates considerations of individual choice and motivation to a position of undeserved prominence"(Rawls

11 Anne Rawls' work draws on previous research in the variegated tradition of social interactionism and gives to some of these authors' ideas a more explicit normative twist. For further details on the normative implications of interactionist sociologies as well as for a more extended discussion of Rawl's proposal, see Frega (2015). 
2009, p. 503). On the other hand, summary order refers to a concept of social order in which meaning and coordinate individual action are produced by the structural operating of super-ordained institutions. This is what happens, for example, when we assume that well designed political institutions - J. Rawls' well ordered society - are a sufficient condition for achieving a given normative goal, such as justice or democracy. In both cases, which correspond to the two poles of substantialist ontologies identified above, the causal as well as normative effects of interactions among individuals within social settings are systematically neglected, their normative content being reduced to the effect either of individuals' rational actions, or of institutional constraints. Under the influence of this conception of social order, individuals and institutions are the sole entities endowed with legitimate normative power.

The constitutive power of interactions, social interactionists contend, derives neither from macro-level social structures, nor from micro-level individual agency, but is based on constraints and normative expectations which emanate from the interaction situation itself. What is missing from institutional accounts of social order, is precisely an account of how social order is not produced through the top-down operating of formal institutions or application of norms, nor through the aggregation of individual actions but, rather by the logic of interaction itself. Whilst social interactionists concur that social institutions cannot be reduced to sets of interactions, they nevertheless contend that interactions, too, cannot be reduced to the enactment of institutional norms and values. Both kinds of orders - the institutional and the interaction - are necessary for a social unit to exist, insofar as each of them refer to a different way of producing normative power.

The concept of order of interaction elaborates J. Rawls' notion of practicerule in a way that sheds light on the ontological effects of social interactions, showing how everyday interactions create social reality, by contributing to the production of interacting individuals as well as of institutional orders. "The idea behind the constitutive order approach is that in order to live in a mutually intelligible world as social beings, with mutually intelligible social identities, reasons and purposes, people must be guided by some set of rules, expectations or preferred orders of action at a basic level” (Rawls 2009, p. 510). Social practices, as J. Rawls has noted, creates normative orders by establishing rules of conduct whose respect is a constitutive feature of the practices themselves. Actors participating in practices do not act out of autonomous judgments, nor under the pressure of external coercion, but because they comply with rules that are constitutive of the practice to which they participate. These rules are immanent to the interaction itself. For this reason, the order of interaction so established "is in essential ways independent of and resistant to social institutions and based on a working consensus between participants” (Rawls 2010, p. 98). This working 
consensus is the source of the normative legitimacy of the order of interaction. Social expectations and orientations are, therefore, produced and entertained by and through interactions, without the necessary intervention of ex-ante stipulative conventions (social contracts). Orders of interaction as "self-regulating practices” (Rawls 2009, p. 511) produce their own ordered evolution in real time, out of constraints that emerge within interactions themselves, rather than being imposed by external instances. In them, social actors do not "follow rules", but, somehow, participate to an interaction order whose survival depends also from their active contribution. As A. Rawls explains with reference to the work of Ervin Goffman, "the individual is never secure in an encounter [...]. It is, therefore, not only moral, but also prudent to act in accordance with the working consensus because violating it would upset the interaction upon which the maintenance of 'self' depends. [...] The dependence of the self and interaction upon adherence to 'involvement obligations' places constraints on the social order itself. These constraints however, do not arise from social structure, class relations, the division of labor, or cultural ideas, but rather from the requirements of the self and sociality" Rawls (1987, p. 140). They are incumbent on participants in an interaction solely on the basis of their engagement in interaction, irrespective of any institutional status or role which they may claim. These constraints, moreover, are indispensable for the furtherance of the interaction. "When the 'working consensus' is violated, interaction collapses” Rawls (1987, p. 141), as shown for example by Harold Garfinkel's “breaching experiments” and by Goffman studies on "face work”.

Orders of interactions are practices in the sense that they are constituted by systems of expectations which define the meaning and value of any event related to them. The interactions among stranger waiting in a line to catch a bus, or exchanging excuses in a public place creates normative orders which are, at least partially, autonomous from individual wills and social norms, as the furtherance of the interaction exacts upon them specific requests. Besides individuals and institutions, interactions emerge, therefore, as a primitive sources of normative order within social life. Scholars in the interactionist tradition from Durkheim to Rawls and Collins have, for example, emphasized the importance of rituals in giving social interactions their normative consistence. Rituals such as greetings or code dress confirm social members about the norms that govern their intercourse, and their breach is usually faced with normative sanctioning by other members. Interactions confirm and reinforce, or contest and undermine, socially shared normative expectations and to this extent have a normative force of their own. ${ }^{12}$

12 See Collins (2004) for an analysis of interaction rituals as being at the same time conservative and capable of creating new normative orders. 
Patterns of social interaction as these are emergent in the sense that their normative properties - what hold as valid norms of appropriate behavior - cannot be derived from either individual or institutional properties. Emergence has to be understood in two senses. According to the first, social situations within which interactions take place operate as "normative ecologies" in which norms of appropriate behavior exist and are preserved through habits and forms of organization. According to to the second, the interaction itself is the arena where, in partial autonomy from external normative expectations and constraints, a normative order is produced through the give and take among those individuals which take part to the interaction itself. A. Rawls' account focuses exclusively on the second dimension, whereas I contend that both are relevant to understand the normative relevance of social interactions. ${ }^{13}$ Combined together, these two interpretations help explain why normative theory must take into account the way social interactions contribute to the creation of the normative order upon which social reality relies. Far from denying the impact of rational individual action and institutional operation, social interactionists contend that there is an additional source of normative order whose effects and implications have not been adequately taken into account.

This approach lends credit to the idea defended in this paper that in-between individual expectations such as political preferences and actions on the one hand, and structural normative demands such as those imposed by formal political institutions on the other, there lies a complex intermediate system of normative expectations which emerge out of social interactions which can be reduced to neither. There is, therefore, no valid justification to limiting our account of political norms and values to the normative role played by individual and structural phenomena. As I will explain in Section 5, not only because habits are more important guides for action than beliefs. Moreover, because social interactions is what politics is all about: we want people to have democratic beliefs, and we want democratic political institutions not for their own sake, but because we prize certain ways of being together, we assign values to how individuals treat each others: not only how representatives treat us in our capacity as citizens but, more generally, how we interact in all the walks of life: as employer and employee, professor and student, public officer and citizen, parent and children, and so on.

13 I justify this claim in Frega (2015). 


\section{The Normative Consequences of Orders of Interaction}

The lesson that can be drawn from the previous two sections is that interactionist approaches are relevant for democratic theory for at least two reasons, one empirical and the other theoretical. On the one hand, in modern societies characterized by increasing levels of individual autonomy, formal institutions play a diminished role in steering social life. Insofar as social coordination is increasingly based on individual autonomy within egalitarian interactions that depend on a lesser extent from predefined social statuses, individuals as well as groups and organizations are increasingly pressed to autonomously establish the terms of their mutual interactions. Interactions within a society of equals are no more regulated by clearly defined social expectations and status-based obligations as it was common in traditional societies, so that social interactions can rely on nothing more than individuals' willingness to participate and to negotiate the content and form of these interactions on a real time basis. ${ }^{14}$ But also at institutional level, global normative orders are increasingly shaped by informal agreements among heterogenous types of institutions interacting in a normative space that lacks the constitutive features presumed by traditional substantialist ontologies. ${ }^{15}$ For these reasons, the normative relevance of patterns of interaction tends to increase. On the other hand, if political institutions are but one of the factors shaping the normative order of a political community, and if orders of interaction contribute as much as political institutions to fashioning social life, then the political quality of a social unit will depend as much on the one as on the other.

Drawing on social interactionism, we can say that the orders of interaction govern everyday social life in at least three ways. First, they help specify and adjust to local circumstances the explicit rules set up by formal institutions. Second, they establish tacit patterns of interaction which produce social coordination in settings not covered by formal rules. Third, they provide the basis upon which processes of institutionalization are built. All three ways are relevant for a theory of democracy, although for different reasons.

14 This is the most ambitious theoretical conclusion that can be drawn from the work of social theorists such as Ervin Goffman and Harold Garfinkel. Modernization theory in the wake of Ulrich Beck has come to very similar conclusions.

15 The decline of a formal system of international relations has been notably described by Koskenniemi (2006). IR studies such as (Krisch 2010), and studies of global commercial law such as (Cutler 2003) have equally documented the emergence of a new logic of global relations where formal agreements and public formal political institutions play an increasingly narrow role. 
1. Social interactionists among others have investigated how the concrete everyday functioning of institutions of any kind depend more directly on tacit orders of interaction than on formal rules. In political science, studies of political culture have developed a similar argument, showing to what extent formal institutions can be hollowed out by informal practices that contradict them. Studies of “defective democracies" (Merkel 2004), have documented at great length that when formal political institutions are embedded within a political culture that is based on different normative principles, they systematically fail to deliver the political goods they are expected to produce. Indeed, it is by engaging in everyday patterns of social interactions that individuals make sense of incompletely specified rules and institutional expectations. Relational conceptions of rights, ${ }^{16}$ for example, show that the effectiveness of rights does not derive from its being possessed by an individual and protected by a state: its concrete content is indeed specified by the interactionist contexts within which it is applied. ${ }^{17}$ They are tools of communal dialogue, "the articulation of legal consequences for particular patterns of human and institutional relationships”, (Minow 1986, p. 1884).

2. Interactions among strangers or in public places have usually remained at the margins of normative accounts of democracy because of their apparent irrelevance, essentially because they fall outside the scope of formal political institutions. Yet these interactions are normatively relevant insofar as they can be assessed in terms of democratic criteria such as freedom, equality, and solidarity. Patterns of interaction, even outside the scope of politics, are pervaded by power relations, enact patterns of authority, show or deny respect. They incarnate political ideas concerning the status of citizenship, express feelings of equality or superiority toward others, produce inclusion or exclusion, promote or prevent individual freedom. Whilst many of these interactions fall outside the scope of legal protections, they play however a major role in making a given idea of the political community real, and to this extent they greatly matter for our understanding of the meaning of democracy.

3. As civil movements have shown, legal protections often evolve out of social experiences where new patterns of social interaction are experimented. One has to think at the revolt against authority in student movements, at the quest

16 "Rights are free-floating cultural and institutional resources that must be appropriated and in turn given meaning only in the practical context of power and social relations”, (Somers 1994, p. 79).

17 "Legal rights, then, should be understood as the language of a continuing process rather than the fixed rules. Rights discourse reaches temporary resting points from which new claims can be made", (Minow 1986, p. 1876). 
for solidarity within labor movements, or at the struggle for freedom within racial movements. In all these cases, we see how patterns of social interaction first experimented within a limited social group, succeed to become dominant in the entire society and, through legal protection, to be formally embedded in the basic political institutions of society. ${ }^{18}$

With the exception of this last example, these facts cannot be explained in terms of a mere anticipation of future institutional solutions, showing that orders of interaction are irreducible to and complements the institutional order created by formal social and political institutions. It follows that the relation between institutional orders and orders of interaction cannot be explained away as an instance of the rule-application or explicit-tacit case. Orders of interaction are not mere informal patterns waiting to be replaced by more explicit institutional settings. They fulfill normative functions that differ from those pursued by institutional orders to which they cannot, therefore, be reduced. ${ }^{19}$

\section{A Social Ontology of Habits, Patterns, Forms}

What has been said so far can be condensed in two major claims. The first establishes the ontological priority of social interactions in the making of social life. The second states the necessity to integrate two normative logics, epitomized by the Rawlsian formulas of summary and practice order, so as to include in our explanatory model all the sources of normative order identified so far. The hypothesis I formulate is that a sufficiently complex theory of individual habits, patterns of interactions, and organizational forms, provides the most promising solution to account for the social complexities related to the functioning of norms highlighted by social interactionists. ${ }^{20}$ As I will contend in this section, these

18 See Dewey (2015) for an interpretation of the normative relevance of social movements along these lines.

19 Social and political sciences have generally tended to solve the problem of the incompleteness of rules and institutions by introducing intermediating factors such as "values". This solution encounters at least two major problems. The first is that it is exposed to the risk of an infinite regress, as it has been pointed out by Steven Turner (Turner 1994). The second is that values explain nothing, unless they are endowed with some form of causal power, which in turn calls for social mechanisms of a different kind (Swidler 1986). The patterns of social interaction analyzed and theorized by social interactionists fulfill this goal.

20 I develop this social ontological account in much greater details in (Frega 2019), where I also trace the historical roots of this approach to the American tradition of pragmatism in philosophy as well as in the social sciences. 
three notions play a specific and primitive role in the explanation of social reality, so that any explanation of social and political phenomena that fails to take one of them into consideration will inevitably be incomplete. ${ }^{21}$

As stated at the outset, social interactions are the primitive fact out of which social life is composed. Yet social interactions as such are a magmatic, unstable, ever changing material, characterized by singularity and fragmentation. What, then, gives social life its stability and consistency? How is it that social interactions do occur on more or less predictable ways, that social life does not always crumbles into chaos? How do normative orders succeed to steer social life? Social life relies upon stabilizers that operate at the three ontological levels identified by the two conceptions of social order discussed so far, the substantialist and the interactionist. Individual habits, patterns of social interaction, and forms of organization play this stabilizing role, introducing regularity within the otherwise unruly and chaotic space of social interactions. They help describe with the same concepts the normative autonomy of the order of interaction as well as the ongoing and mutual influences between the levels of individual and structural properties that compose the institutional order, shedding light on the interaction between individual features such as actions and beliefs, and general patterns and structures. In so doing, they provide a theoretical framework capable of questioning the mutual and reciprocal effects that each level produces on the other. Such a complex framework is necessary if we want to avoid falling in the symmetrical traps of methodological individualism and institutional determinism to which so much of contemporary political science - and political theory as well - continue to subscribe.

This ontology reflects a mild form of realism, ${ }^{22}$ according to which ideas, values, culture, and other symbolic entities enter the world through specific forms of embodiment, of which habits, routines, procedures, organizational forms are the most explicit examples (Swidler 1986). Whilst symbolic entities do not count among the basic ingredient of the social ontology here presented, they are nevertheless essential ingredients of our social world: how could one provide an account of democracy without making reference to the values of freedom, equality, and solidarity? From the social-interactionist ontological standpoint here developed, values and norms are ineffectual and, therefore, unreal, till they become embodied in individual habits, patterns of social interaction, and forms of organization. These last are, indeed, the doorway through which symbolic

21 To that extent, I disagree with Italo Testa, who considers that a social ontology inspired by pragmatism can be easily reduced to the notion of habit. See Testa (2016).

22 John Dewey and Hilary Putnam are the forerunners of this kind of realism. Along similar lines, see also Abbott (2016). 
artifacts enter the social world. Rather than beginning by defining freedom as a value, we should consider which individual habits, patterns of social interaction, and organizational forms may promote or prevent the spread of free interactions. Only then we will have reached a satisfying understanding of freedom.

\subsection{Individual Habits}

Whilst it may not be extremely fashionable today, the concept of habit has constituted one of the main staple of social theory since its very inception in the 19th century (Camic 1986). Although we owe to American pragmatists and sociologists from the Chicago School its most explicit use and theorization, ${ }^{23}$ the notion of habits played a significant role also in the social theories of their contemporaries Emile Durkheim and Max Weber, as well as, later, in the social theory of Pierre Bourdieu and, closer to us, in debates about attitudes, particularly within social ontology. ${ }^{24}$ Common to these otherwise diverse approaches, and contrary to rival approaches to action such as rational choice theory, is the idea that intentional action is rare because costly. ${ }^{25}$ Habits, rather than intentions, are seen as the most important source of action. Habits are learned dispositions to act in similar manners when similar circumstances occur, or are perceived to occur. Central to the notion of habit is the idea that social order relies to a significant extent on routinized behavior, rather than on intentional states. Actors - and citizens among them - develop repertoires of routine responses to life situations, habitualized ways of answering in similar ways to similar circumstances. In that way, habits support individuals' intercourses in life world situations, influence their behavior, guide their conduct, and in that way determine the normative quality of associated life. Habit, in the compelling formula of William James, is "the enormous fly-wheel of society, its most precious conservative agent. It alone is what keeps us all within the bounds of ordinance, and saves the children of fortune from the envious uprisings of the poor. It alone prevents the hardest and most repulsive

23 The most comprehensive study to date on the role of the concept of habit in these two traditions is Kilpinen (2000).

24 See, for example, Fara (2005). I prefer the more classical notion of habit to that of attitudes because I want to avoid confusion with approaches to social ontology which understand the social world in terms of conventions and see social objects as projections of our attitudes or agreements onto the nonsocial world. In my view, this strategy overemphasizes the performative role of language and intentions, as is typically the case of Searle.

25 This point has been emphasized by philosophical anthropologists such as Helmut Plessner as well as by many representative of institutional economics. For this last, see Hodgson (2004). 
walks of life from being deserted by those brought up to tread therein..." (James 1950, p. 121). Another representative of American pragmatism, John Dewey, saw in habits the cornerstone of social psychology. He notably contended that "[h]abit is the mainspring of human action, and habits are formed for the most part under the influence of the customs of a group. The organic structure of man entails the formation of habit, for, whether we wish it or not, whether we are aware of it or not, every act effects a modification of attitude and set which directs future behavior" (Dewey 1927, p. lw2.334-5).

In all these traditions, the notion of habit is at the roots of a conception of social action that purports to overcome the limitations of a model of explanations of individual behavior that gives priority to individuals' intentional states. According to intentionalist accounts, action arises from motives intentionally set or pursued by individuals relying on individual states such as preferences, interests, beliefs, or affective states, so that individual action can be accounted for in terms of its instrumental adequacy to fulfill these intentional states. Action that is not fully reflexive is often taken to be irrational. Purposefulness is what makes action distinctively human, its opposite being dull routine, non reflexive following of rules. In direct opposition to intentionalist accounts of action, habit-based theories emphasize the value and rationality of non-intentional patterns of behavior. They contend that habits more than intentions do the largest part of the normative work which is required for achieving social cooperation. Habits incorporate norms and translate them in regular patterns of behavior integrating a living being in his/her environment. The relation between habits and the environment is bi-directional. On the one hand, the outer environment shapes habits through processes of socialization. Social circumstances are also responsible for the activation or inhibition of specific habits, which can be masked without being changed. Processes of socialization and masking denote different ways whereby the environment influences agents' habitual responses. On the other hand, habits shape the social environment by producing regular and expectable patterns of action. Social action is, therefore, essentially shaped by habit, which in turn is shaped by social circumstances. Habit is, however, a reflexive dispositional property, which means that it encompasses a degree of flexibility, something conveyed by the concept of learning. As a consequence, habit are not the blind repetition of the same behavioral sequence, such as in a stimulus-response pattern. As scholars in the social interactionist tradition have contended, habitual tendencies or dispositions are neither rigid nor blind, and the feedback obtained by their exercise can lead to their modification.

While habitual accounts of action are quite diffused in psychology, anthropology, sociology, and economics, they have traditionally played a less significant function in political theory. However, adopting a habit-based theory of 
action may bear significant consequences in this domain too. With reference to democratic theory, a habitual account of action may contribute to challenging the idea that intentional states are the sole sources of democratic legitimacy. ${ }^{26}$ Political theorists tend to think that political behavior is fully rational only when based on intentional states (rational preferences), and irrational otherwise. A habit-based conception of social action reverses this view insofar as it points to rational sources that are embedded in habitual action, rather than opposed to it. For example, an actor's routinely voting for the same party, or reacting in the same way when she perceives a social interaction as unjust, does not mean that her behavior is irrational, blind. Moreover, the habitual structure of action does in no way pre-empt the freedom to act and react otherwise, were one to perceive the relevant circumstances under a different light. But habits can be at odds with an actor's intentional states, and lead to actions opposite to those that we would predict when relying on knowledge of his explicit beliefs. For example, undemocratic behavior such as racial discrimination can happen under the cover of genuinely non-racist intentional states. Debates in critical race theory have notably shown that racial and discriminatory attitudes are often tacitly inscribed in ways of acting of which the agent is often unaware, so that an individual may combine the abstract endorsement of anti-racist values - and the self-deluded idea of not being a racist - with deeply engrained racial habits. ${ }^{27}$ The obvious consequence is that undemocratic norms may well continue to persist under the guise of tacit and non-problematized undemocratic habits. We know today beyond reasonable doubt that forms of privilege and discrimination such as those associated with gender, race, religion, social status operate as unseen, invisible, even seemingly nonexistent determinants of action. The obvious implication of this analysis in terms of habits is that we should devise social and political means to develop democratic habits, rather than continue to focus on the question of how to democratize values or ideas.

According to habit-based theories of action, to fully understand and explain political behavior we need to drop classical means-end individualistic conceptions of human rationality, to adopt instead a broader view of the rationality of action that is adaptive, temporally extended, and collective. While I cannot enter into a detailed analysis here, ${ }^{28}$ it can at least be pointed out that such a conception of rationality emphasizes that what appear irrational from the perspective

26 Achen and Bartels (2016) is a clear example of how this assumption dominates normative as well as empirical studies. I explore this line of criticism in details in Frega (2018).

27 See for example Sullivan (2006); MacMullan (2009), both explicitly relying on habit as a key concept to analyze and criticize contemporary forms of racism.

28 But see Frega (2018). 
of the actual match between an individual's beliefs and his actions, may reveal a higher degree of rationality when seen in the medium-long term perspective that habits require to adjust to changed situations. Studies of political behavior show for example that mismatch between preferences and behavior may take as long as a generation to be overcome. This fact, when seen from the usual individualistic theory of rationality cannot but appear irrational, as scholars of political behavior have often noted. On the other hand, if we consider rationality to be an adaptive strategy, then the kind of inertia introduced by habits appears as a powerful stabilizer that help a society avoid the potential disruption produced by more rapid forms of behavioral adjustment to local circumstances.

These examples show that intentional states such as beliefs are often the result of less reflective and more permanent states such as habits and dispositions. The upshot of this view is twofold. First, agent's consistency and rationality should be interpreted in the long term perspective of habitualized patterns of thinking and action, rather than in those of a local correspondence between action and belief at a given point in time. Second, habits have a normative relevance of their own in explaining individuals' behavior, so that habits turn out to be more important predictors of democratic behavior than beliefs. In other words, to predict a society's degree of compliance with democratic norms, we should investigate people's habits, rather than people's values and beliefs. Not a small a revolution for contemporary political science.

\subsection{Patterns of Social Interaction}

As explained in Section 3, patterns of social interaction ${ }^{29}$ define an interstitial dimension of social order which nests between the level of individual habits, values and preferences on the one hand, and the social level of institutionally organized forms on the other. Whilst habits are the material upon which social interactions are established, habits alone are not a sufficient condition for the existence of a normative order, their actualization depending upon contextual circumstances. Indeed, as the section on interactional order has shown, social interactions are shaped also by factors which are immanent to interactions themselves. Certainly, if individuals were not capable of stable dispositions to act, social regularities in conduct would be extremely difficult to achieve. These regularities, however, must be kept ontologically distinct from individual habits, and

29 I use the expression "patterns of social interaction" instead of order of interaction to avoid confusing my own approach with A. Rawls'. Yet the idea of pattern, like that of order, refers to a set of norms that regulates and organizes a plurality of interactions. 
the notion of patterns of social interaction is, to this extent, preferable to that of collective habits, as it helps avoiding confusion between the two levels.

Individuals encounter the outer social world as a world full with normative expectations, usually wrapped up in sanctioned ways of saying and doing. Patterns of interaction involve a plurality of individuals (at least two), for example the way in which a customer and a shopkeeper interact during their commercial transaction, or the way two strangers look at each other and maybe solve interactional troubles such as rights of precedence when jumping on a bus. But there are also, as explained above, the normative orders that are immanent to interactions themselves, for example the way strangers stand in line waiting their turn to be served, usually respecting an order of precedence while being sensitive to exceptions and circumstances, without needing every time to re-establish queuing rules (Goffman 1983). Patterns are immanent to social situations in a way that habits are not. It is indeed in interaction with others that individual dispositions may give rise to social regularities. A pattern of social interaction is a form of regularity that characterizes social interactions, transforming disparate interactions into a social practice endowed with its own normative order. Patterns need not be rooted in explicit norms such as legal codes, although this may sometimes be the case. Either way, patterns of social interaction embed norms establishing expectations concerning how individuals should treat each other according to variables which are generally related to two types of conditions: individual status and situational circumstances.

Status-based variables have dominated the largest part of human associated living, where patterns of interaction have been codified according to status markers such as the gender, age, race, education, religion, or economic position of the interacting partners. In non-egalitarian societies, as was notably the case in European societies of ancien régime, social status defines positional roles which in turn specify asymmetric rights and duties. Status based positional roles cannot be exchanged, and define therefore non-reciprocal and fixed types of relations among social actors. In egalitarian societies, patterns of interaction tend to be shaped by roles which are designed according to functional expectations, and which in principle can be occupied by every individual, such as employer or employee, public officer, teacher, student, parent, or child. Patterns of interaction are obviously also context dependent: workplaces elicit interaction patterns that differ from those elicited by schools or by families. Moreover, different types of workplaces, or different families, elicit in turn diverse patterns of social interaction.

Patterns of social interaction instantiate in the most concrete way the way individuals treat each other, and to this extent they are politics made flesh. At its deepest, political experience is relational: it is the experience of how a representative interacts with those he or she represents, of how a man interacts 
with a woman, a White with a Black, a catholic with a muslim, an employer with an employee, a father with a son, a citizen with an immigrant, a stranger with another stranger. We experience the social world as a world of relations, we value others in terms not only of their qualities, but especially of the relations we can establish with them (Kolodny 2003). Spatial segregation in racialized societies, rules of precedence during the ancien régime, forms of gendered deference in traditional societies, relations of subordination in a capitalist system, distribution of authority according to age groups, are among the politically most relevant patterns of social interaction. Even when these patterns are not specified in explicit norms, they shape collective life in depth, by establishing how someone's status determines her role within social relations. These patterns of interaction specify authorized and prohibited types of relations, give shape to legitimate expectations, and tacitly define the limits of what one is entitled to expect and do in a given social interaction. They define the overall social framework that make social encounters possible, and that establishes its very possibilities. Social interactions do never take place in the void, but always within the framework of patterned social expectations.

Whilst generally neglected by democratic theory, ${ }^{30}$ patterns of social interaction have been acknowledged by social theory as a central feature of politics. Their political relevance is twofold. On the one hand, patterns of social interaction translate normative principles into concrete social relations, giving visible form to what a social group considers legitimate ways of treating others. On the other hand, they provide the arena where social norms can be contested and transformed. Studies in the tradition of social interactionism have notably shown the relevance of social encounters for the negotiation of normative orders. One can refer also to studies of social movements as they show how new relational experiences have been at the origin of deep transformations in political values, of how negotiations of the interaction order brought about by marginalized individuals and groups have deeply transformed our understanding of the basic normative principles which define democracy. In these and similar cases what is at stake is not the simple demand of a more consistent application of norms whose content is already established but, rather, the re-creation of the normative principles which guide established patterns of social interaction. It is indeed by challenging these patterns that our understanding of what equality means, of what legitimates authority, of what qualifies as a form of exclusion, of what it means to be free, has been shaped.

30 There are of course exceptions, but they usually concern specific situations or examples. There is no study that I am aware of that tackles this question at the theoretical level of a theory of democracy. 


\subsection{Forms of Organization}

By forms of organization I refer to the institutionalized arrangements through which a social unit achieves the internal coordination of its forces. They include decision-making procedures, operating rules, statutes and codes, temporal and spatial arrangements, organizational schemes of work, institutional design, formal roles. They possess a degree of formalization and institutionalization unmatched by patterns of social interaction. Moreover, they are usually the result of an intentional process aimed at introducing regularity within social interactions, and they often rely on forms of material support, a point that has been convincingly explained by ANT theory. ${ }^{31}$ Forms of organizations shape and orient social interactions from the level of loosely structured voluntary organizations such as neighborhood associations to that of highly sophisticated business corporations, churches, or political systems. Forms of organization stabilize social interactions by making them explicit. They are "concerted methods of regulated interaction” (Dewey 1925, p. LW1:154). Even granting that society consists mostly of regulated and repeated interactions, recursiveness and repetition require some form of external support to persist in time. This function is accomplished by organizational forms such as firms and hospitals, and by institutions such as markets and the state. Besides accomplishing functions that are necessary for the survival of a social unit in time, organizations and institutions play also a major role in enabling and constraining social interactions. First, by constituting arenas where individuals interact according to highly codified patterns. Second, by setting the terms of broader interactional schemes, as is the case of institutions such as the market, but also such as the marriage. In either way, by imposing regular patterns of behavior, they orient social interactions and shape individual habits, producing a sort of "downward causation" from institutions to individuals. As institutionalists contend, this process is mediated through habits, rather than through instincts, behavior, or intentional states (Hodgson 2004).

Institutions such as the corporation, the liberal state, the bureaucracy, the university have organizational forms: concrete assemblage of rules, roles, material artifacts that in different ways contribute to stabilizing patterns of social interaction. These institutional arrangements enable or constrain individual freedom, promote or hamper egalitarian relations, favor or restrain the development of cooperative and solidaristic interactions among social members. In these and related manners, social and political institutions concretely produce and

31 See, for example Marres (2016). 
reproduce normative orders. In so doing, they help sustain or impede the democratization of a society and play a great role in the implementation of democratic norms. The implication of this approach for democratic theory is quite straightforward and amounts to a significant enlargement of the institutional scope of a normative theory of democracy. On the one hand, by extending the scope of democracy as a method for decision-making and conflict-resolution beyond the scope of formal political institutions: participatory schemes within private firms, accountable delegation to management, cooperative learning methods within educational institutions, new forms of peer production, are some examples of how democratic norms can steer a social unit. Organizations can also be sites of normative innovation: sites where abstract ideas and principles are translated into practice, their consequences assessed, their meaning transformed accordingly. ${ }^{32}$ On the other hand, by investigating the normative quality of organizational structures as such, asking how the organizational form adopted by a given social unit promotes or hampers the actuation of the norms that define democracy as a social idea. Workplace life is a paradigmatic case of a social unit in which the question of the democratic implications of forms of organization is most evident, in both meanings noted above. One may inquire for example into how representative or direct forms of participation are or should be implemented within private firms. But one may also discuss how normative expectations are embedded in the design of models of production, in the definition of professional roles, in the distribution of functions across units, or in the re-organization of work and leisure spaces. When examined from the perspective of an interactionist social ontology, the democratization of the workplace appears to largely exceed the conventional concern for accountability, decision-making, or self-government.

\section{Conclusion}

In its anti-idealist stance, the social ontology of democracy tells us that it is through their embodiment in the individual habits, patterns of social interaction, and organizational forms that values and norms shape and organize everyday social interactions. Without this ontological rooting, values and norms would remain detached and devoid of concrete efficacy. Democracy as a norm for social life, therefore, exists only thanks to the specific habits, patterns and forms that enable and promote interactions among human beings that we qualify as democratic. The task of a social ontology of democracy consists, therefore, in artic-

32 This is the most relevant lesson of democratic experimentalism. See Frega (2019, Ch. 7). 
ulating this basic intuition in more specific ways, by explaining which habits, patterns and forms are more conducive to the development of a democratic way of life, by explaining how they concretely shape interactions, by devising effective ways to promote the habits, patterns, and forms most conducive to democratic interactions. Such an approach is, obviously, much more demanding than standard accounts of democracy which are content with listing the institutional arrangements and legal requirements that democracy as a norm exacts on us.

The idea here defended is that whatever the normative principles upon which a democratic theory is built, they need to be articulated in terms of how they are embedded into habits, patterns, and forms, because habits, patterns, and forms have a normative power of their own, the power to bring ideas to life. In other terms, a theory of democracy should be deemed incomplete till its normative expectations will have been specified in terms of which habits, patterns, and forms are required for the democratic norm to effectively steer a given social unit. These requirements will vary according to the basic normative assumptions of which a given theory of democracy consists. Whether one prioritizes freedom, equality, solidarity, or another normative principle, or whether one tries to reconcile them, in every case the theory will have to specify its normative content in terms of the habits, patterns, and forms that will constitute its socio-ontological underpinnings.

Habits, patterns, and forms, in addition, are not general and abstract features, but tend to be highly context dependent, so that implementing democracy as a norm at diverse social sites will likely require the development of habits, patterns, and forms, that at least in part will be site-specific. Indeed, we should not expect that democratizing a national political community, a multinational corporation, a small firm, an educational institutions, a non-profit organization, or a public administration will require the development of the same habits, patterns, and forms. Many will be similar, as the normative core of democracy has features common to most social situations. But there is not much else that can be said in advance of a more detailed empirical investigation of the type of social unit in question. Such an investigation is needed in order to clarify its social functions, external and internal constraints, existing social roles, the nature of the expectations as well as of the obligations it forces upon its members. A child in a family, a pupil in a school, an employee in a firm, and a citizen in a state are all to a certain extent dependent and subordinate individuals within a web of social relations. Yet the kind of asymmetric authority to which they are subjected, the nature and the consequences of the authority relations, the type of freedom to which each role entitles one, the nature of equality each relation creates, are so diverse that very different normative expectations are indeed appropriate for each of these social units. Therefore, what may prove to be legitimate and consistent with the 
democratic norm within one of these social units, may prove illegitimate and undemocratic when transferred to another type of social unit.

This approach can be applied to a variety of social settings such as the workplace, social and political movements, private and public institutions, political parties, and political communities. Thanks to its solid roots in social theory, this approach will likely provide precise clues about how to improve the democratic quality of a social unit, and to develop specific policy guidelines to tackle the deep democratic deficits we are facing today. In conclusion, the generative power of habits, patterns, and forms, supported by processes of habitualization and institutionalization, provides the conceptual mediation to explain how normative principles can be embedded in social life, and transformed in concrete patterns of action.

Acknowledgements: Previous versions of this paper have been presented the workshop "Pragmatism for social scientists" hosted at the Department of Conflict and Development Studies at Ghent University (March 16th 2018) and at the conference "Democracy and forms of life" held at the Centre Marc Bloch (April 24th, 2018). I thank the organizers and participants for the feedback received. I also want to thank Roberto Gronda, Tullio Viola, and two anonymous reviewers of this journal for their useful comments and criticisms.

\section{Bibliography}

Abbott, A. (1999): Department and Discipline: Chicago Sociology at One Hundred. Chicago:

University of Chicago Press.

Abbott, A. (2007): “Mechanisms and Relations". In: Sociologica 1. No. 2, p. 1-22.

Abbott, A. (2016): Processual Sociology. Chicago: University of Chicago Press.

Achen, C. and L. Bartels (2016): Democracy for Realists: Why Elections Do Not Produce Responsive Government. Princeton: Princeton University Press.

Archer, M. (1995): Realist Social Theory: The Morphogenetic Approach. Cambridge: Cambridge University Press.

Bentley, A. (1908): The Process of Government, a Study of Social Pressures by Arthur F. Bentley. Chicago: Chicago University Press.

Bulmer, M. (1986): The Chicago School of Sociology: Institutionalization, Diversity, and the Rise of Sociological Research. Chicago: University of Chicago Press.

Camic, C. (1986): “The Matter of Habit”. American Journal of Sociology p. 1039-1087.

Collins, R. (2004): Interaction Ritual Chains. Princeton University Press.

Cooley, C. (1918): Social Process. New York: Scribner's.

Cutler, A. C. (2003): Private Power and Global Authority: Transnational Merchant Law in the Global Political Economy, Volume 90. Cambridge: Cambridge University Press.

Dépelteau, F. (2018): The Palgrave Handbook of Relational Sociology. Cham: Palgrave Macmillan. 
Dewey, J. (1925): Experience and Nature. The Later Works, 1925-1953, vol. 1. Carbondale: Southern Illinois University Press.

Dewey, J. (1927): The Public and its Problems. The Later Works, 1925-1953, vol. 2. Carbondale: Southern Illinois University Press.

Dewey, J. (1928): "Social as a Category". In: The Monist p. 161-177.

Dewey, J. (1939): “Creative Democracy: The Task Before Us”. In: The Later Works, 1925-1953, vol. 14. Carbondale: Southern Illinois University Press.

Dewey, J. (2015): “Lectures in Social and Political Philosophy”. In: European Journal of Pragmatism and American Philosophy, p. 7-44.

Elder-Vass, D. (2010): The Causal Power of Social Structures: Emergence, Structure and Agency. Cambridge: Cambridge University Press.

Emirbayer, M. (1997): “Manifesto for a Relational Sociology”. In: American Journal of Sociology 103. No. 2, p. 281-317.

Epstein, B. (2015): The Ant Trap: Rebuilding the Foundations of the Social Sciences. Oxford: Oxford University Press.

Fara, M. (2005): “Dispositions and Habituals”. In: Noûs 39. No. 1, p. 43-82.

Follett, M. P. (1919): “Community is a Process”. In: The Philosophical Review, p. 576-588.

Frega, R. (2015): “The Normative Structure of the Ordinary”. In: European Journal of Pragmatism and American Philosophy 7. No. 1, p. 54-76.

Frega, R. (2017a): “The Normativity of Democracy”. In: European Journal of Political Theory Online First.

Frega, R. (2017b): “The Wide View of Democracy”. In: Thesis Eleven 140. No. 1, p. 3-21.

Frega, R. (2018): “Democracy and the Limits of Political Realism”. In: Critical Review of International Social and Political Philosophy Online First.

Frega, R. (2019): Pragmatism and the Wide View of Democracy. Basingstoke: Palgrave Macmillan.

Giddens, A. (1984): The Constitution of Society. Cambridge: Polity Press.

Goffman, E. (1983): “The Interaction Order: American Sociological Association, 1982 Presidential Address". In: American Sociological Review 48. No. 1, p. 1-17.

Gould, C. (1978): Marx's Social Ontology: Individuality and Community in Marx's Theory of Social Reality. Cambridge, MA: Mit Press.

Gould, C. (1988): Rethinking Democracy. Cambridge: Cambrdge University Press.

Hay, C. (2006): "Political Ontology”. In: R. E. Goodin and C. Tilly (Ed.): The Oxford Handbook of Contextual Political Analysis, p. 78-96. Oxford: Oxford University Press.

Hodgson, G. M. (2004): “Reclaiming Habit for Institutional Economics”. In: Journal of Economic Psychology 25. No. 5, p. 651-660.

James, W. (1950): The Principles of Psychology: In 2 volumes (First ed. 1890 ed.). Dover Publishing.

Kilpinen, E. (2000): The Enormous Fly-Wheel of Society: Pragmatism's Habitual Conception of Action and Social Theory. Helsinki: University of Helsinki.

Kolodny, N. (2003): “Love as Valuing a Relationship”. In: The Philosophical Review 112. No. 2, p. 135-189.

Korbut, A. (2014): “The Idea of Constitutive Order in Ethnomethodology”. In: European Journal of Social Theory 17. No. 4, p. 479-496.

Koskenniemi, M. (2006): From Apology to Utopia. The structure of International Legal Argument. Cambridge: Cambrdge University Press. 
Krisch, N. (2010): Beyond Constitutionalism: The Pluralist Structure of Postnational Law. Oxford: Oxford University Press.

Lefort, C. (1986): Essais sur le politique. Paris: Éd. du Seuil.

Little, D. (2012): “Explanatory Autonomy and Coleman's Boat”. In: THEORIA. Revista de Teoría, Historia y Fundamentos de la Ciencia 27. No. 2, p. 137-151.

MacMullan, T. (2009): Habits of Whiteness. A Pragmatist Reconstruction. Bloomington: Indiana University Press.

Marres, N. (2016): Material Participation: Technology, The Environment and Everyday Publics. Dordrecht: Springer.

Merkel, W. (2004): “Embedded and Defective Democracies”. In: Democratization 11. No. 5 , p. 33-58.

Minow, M. (1986): “Interpreting Rights: An Essay for Rober Cover”. In: Yale Law Journal Company 96, p. 1860-1915.

Park, R. and E. Burgess (1921): Introduction to the Science of Sociology. Chicago: University of Chicago Press.

Pettit, P. (2005): “Rawls's political ontology”. In: Politics, Philosophy \& Economics 4. No. 2, p. 157-174.

Pettit, P. (2014): “Three Issues in Social Ontology”. See zahle2014rethinking, Chapter 5, p. 77-96.

Popper, K. (1945): The Open Society and its Enemies. Routledge \& K. Paul.

Rawls, J. (1955): “Two Concepts of Rules”. In: The Philosophical Review 64. No. 1, p. 3-32.

Rawls, A. (1987): “The interaction order sui generis: Goffman's Contribution to Social Theory". In: Sociological Theory 5. No. 2, p. 136-149.

Rawls, A. (2009): "An Essay on Two Conceptions of Social Order: Constitutive Orders of Action, Objects and Identities vs Aggregated Orders of Individual Action”. In: Journal of Classical Sociology 9. No. 4, p. 500-520.

Rawls, A. (2010): "Social Order as Moral Order". In: S. Hitlin and S. Vaisey (Ed.): Handbook of the Sociology of Morality. New York: Springer.

Renault, E. (2016): “Critical Theory and Processual Social Ontology”. In: Journal of Social Ontology 2. No. 1, p. 17-32.

Somers, M. R. (1994): “Rights, Relationality, and Membership: Rethinking the Making and Meaning of Citizenship”. In: Law \& Social Inquiry 19. No. 1, p. 63-114.

Sullivan, S. (2006): Revealing Whiteness. Bloomington: Indiana University Press.

Swidler, A. (1986): “Culture in Action: Symbols and Strategies”. In: American Sociological Review, p. 273-286.

Taylor, C. (1985): Philosophical Papers: Volume 1, Human Agency and Language, Volume 1, Chapter Atomism. Cambridge University Press.

Taylor, C. (1995): “Cross-Purposes. The Liberal-Communitarian Debate”. In: Philosophical Arguments, p. 181-203. Cambridge, MA: Harvard University Press.

Testa, I. (2016): “Dewey’s Social Ontology: A Pragmatist Alternative to Searle’s Approach to Social Reality". In: International Journal of Philosophical Studies 25. No. 1, p. 40-62.

Turner, S. (1994): The Social Theory of Practices. Cambridge: Cambridge University Press.

Udehn, L. (2002): Methodological Individualism: Background, History and Meaning. London: Routledge.

Whitehead, A. N. (1929): Process and Reality, an Essay in Cosmology. The University Press.

Zahle, J. and F. Collin (2014): Rethinking the Individualism-Holism Debate. Dordrecht: Springer. 